\title{
Musculoskeletal Imaging for Dermatologists: Techniques in the Diagnosis and Management of Psoriatic Arthritis
}

\author{
Alice B. Gottlieb - Catherine Bakewell · Joseph F. Merola
}

Received: March 24, 2021 / Published online: June 18, 2021

(C) The Author(s) 2021

\begin{abstract}
Psoriatic arthritis is an inflammatory condition affecting up to $30 \%$ of patients with psoriasis. Patients may experience irreversible joint damage if not treated early, and diagnostic delays of even 6 months are associated with radiographic progression and impaired function. Therefore, early detection and intervention are of critical importance in patients with psoriatic arthritis. Given that psoriasis often precedes symptoms of psoriatic arthritis, dermatologists are uniquely positioned to identify patients with psoriatic arthritis early in their disease course, before permanent damage has occurred. Several screening tools have been developed to help dermatologists identify patients who may have psoriatic arthritis, but these tools may not capture patients with subclinical disease or
\end{abstract}

\footnotetext{
A. B. Gottlieb ( $\square)$

Icahn School of Medicine at Mount Sinai, New York, NY, USA

e-mail: alice.gottlieb@mountsinai.org

C. Bakewell

Intermountain Healthcare Medical Group, Salt Lake

City, UT, USA

J. F. Merola

Brigham and Women's Hospital, Harvard Medical

School, Boston, MA, USA
}

quantify the type and severity of the underlying tissue insult, which is often the presenting sign of psoriatic arthritis. In these cases, a combination of clinical assessment and musculoskeletal imaging (e.g., ultrasound) is required. This review summarizes three common musculoskeletal imaging techniques used in the diagnosis and management of patients with psoriatic arthritis: conventional radiography, ultrasound, and magnetic resonance imaging. Further understanding of musculoskeletal imaging will assist dermatologists in making treatment decisions and allow them to have a more active role in the detection of psoriatic arthritis.

Keywords: Psoriasis; Psoriatic arthritis; Radiography; Ultrasound; MRI 


\section{Key Summary Points}

The early detection and appropriate management of psoriatic arthritis (PsA) are critically important in improving patient outcomes.

In many patients who develop PsA, psoriasis precedes arthritis by 7-12 years, ideally positioning dermatologists to identify and treat patients who may have early signs of PsA.

However, PsA is often underdiagnosed in both primary care and dermatology practices; therefore, dermatologists should be encouraged to be proactive during patient visits and inquire about joint pain, consider the possibility of axial disease, and evaluate for tenderness at entheseal sites.

Understanding musculoskeletal imaging techniques that rheumatologists use will increase meaningful collaborations between dermatologists and rheumatologists and aid dermatologists in diagnosing PsA, including subclinical disease, and making timely treatment decisions.

\section{DIGITAL FEATURES}

This article is published with digital features, including a summary slide, to facilitate understanding of the article. To view digital features for this article go to https://doi.org/10.6084/ m9.figshare.14681436.

\section{INTRODUCTION}

Psoriatic arthritis (PsA), a chronic inflammatory disease, is a common comorbidity of psoriasis, affecting up to $30 \%$ of patients $[1,2]$. PsA is a heterogeneous disease with dermatologic and musculoskeletal manifestations-including peripheral and axial arthritis, enthesitis, dactylitis, psoriasis, and psoriatic nail diseasethat is associated with a decreased quality of life and increased morbidity and mortality [3]. Patients may experience progressive, irreversible joint damage if not treated early; even a short delay of 6 months from symptom onset to diagnosis is associated with joint damage and poor long-term physical function [4]. Therefore, early detection and intervention are critical in reducing the extent of detrimental patient outcomes.

In $75-84 \%$ of patients who develop PsA, psoriasis precedes arthritis by 7-12 years [5], giving dermatologists a unique opportunity to identify and treat patients who may have early signs of PsA. However, PsA is often underdiagnosed in both primary care and dermatology practices [6-8]. Therefore, dermatologists are encouraged to be proactive during patient visits and inquire about joint pain, consider the possibility of axial disease, and evaluate for tenderness at entheseal sites [1]. Several validated screening tools $[1,9,10]$ as well as the mnemonic acronym PSA (pain [in the joints], stiffness [ $>30 \mathrm{~min}$ after a period of inactivity]/ sausage digit [dactylitis/swelling], and axial spine involvement/back pain associated with stiffness and pain that improves with activity) have been developed to facilitate rapid screening [10].

Rapid assessment of patients using validated screening tools can identify PsA during routine office visits, whereas clinical assessment may be complemented by musculoskeletal imaging, which can provide key information in the diagnosis of PsA. For example, joint damage characteristic of PsA can be detected and monitored by radiographs, although radiograph findings are often negative in early disease $[11,12]$. Newer imaging techniques, such as ultrasound and magnetic resonance imaging (MRI), can detect early and subclinical PsA signs such as enthesitis and aid in early differentiation of PsA from other conditions such as fibromyalgia [13-15]. The use of imaging may be especially relevant for patients with severe psoriasis, nail pitting, uveitis, inflammatory changes in the axial skeleton (i.e., sacroiliac joints, spine) indicative of axial PsA, or 
nonspecific musculoskeletal symptoms (e.g., fatigue, joint pain, stiffness) [16-20]. Therefore, familiarity with common imaging techniques used in the assessment of PsA can help dermatologists better care for their patients with psoriasis. In this review, we provide an overview of the main musculoskeletal imaging techniques used in the diagnosis and management of PsA. This review is based on previously conducted studies and does not contain any new studies with human participants or animals performed by any of the authors.

\section{Common Imaging Modalities Used in the Diagnosis and Management of PsA}

This section provides a brief overview of conventional radiography, ultrasound, and MRI along with their advantages and disadvantages, the disease stage for which they are best suited, and the features that can be observed (Table 1).

\section{Conventional Radiography}

Conventional radiography is the most commonly used imaging technique for assessing structural damage in PsA $[12,21]$. Radiographs are especially useful in detecting bone erosion

Table 1 Imaging techniques currently used in the diagnosis and analysis of progression of PsA

\begin{tabular}{|c|c|c|c|}
\hline $\begin{array}{l}\text { Imaging } \\
\text { technique }\end{array}$ & Strengths & Weaknesses & Preferred use \\
\hline \multirow[t]{2}{*}{$\mathrm{X}$-ray [23] } & Inexpensive and readily available & $\begin{array}{l}\text { Unable to detect early signs of } \\
\text { subclinical PsA in soft tissues }\end{array}$ & Assessment of clinical PsA \\
\hline & $\begin{array}{l}\text { Can identify joint damage/new } \\
\text { bone formation associated with } \\
\text { more advanced disease (e.g., } \\
\text { erosions and enthesophytes) }\end{array}$ & $\begin{array}{l}\text { Ionizing radiation (doses to hands } \\
\text { are lowest risk) }\end{array}$ & $\begin{array}{l}\text { Detection of joint damage (erosion, } \\
\text { fluffy periostitis, new bone } \\
\text { formation, enthesophytes) and } \\
\text { monitoring of radiographic } \\
\text { progression }\end{array}$ \\
\hline \multirow[t]{4}{*}{ Ultrasound } & $\begin{array}{l}\text { Inexpensive, portable, and readily } \\
\text { available }[26,44]\end{array}$ & $\begin{array}{l}\text { Unable to detect intraosseous } \\
\text { abnormalities due to active } \\
\text { enthesitis, such as bone marrow } \\
\text { edema }[25,79]\end{array}$ & Assessment of preclinical PsA \\
\hline & $\begin{array}{l}\text { Nonionizing and noninvasive } \\
{[26,44]}\end{array}$ & $\begin{array}{l}\text { Weak signals and artifacts due to } \\
\text { small number of blood vessels in } \\
\text { entheses and proximity to bone } \\
\text { [32] }\end{array}$ & $\begin{array}{l}\text { Visualization of the peripheral } \\
\text { joints and entheses for detection } \\
\text { of enthesitis and assessment of } \\
\text { synovial tissue, joint effusions, } \\
\text { and erosions }[23,25]\end{array}$ \\
\hline & $\begin{array}{l}\text { Capability of real-time dynamic } \\
\text { imaging of multiple joints/ } \\
\text { enthuses }[26,44]\end{array}$ & $\begin{array}{l}\text { Lack of standardization among } \\
\text { different machines [80] }\end{array}$ & $\begin{array}{l}\text { Identification of subclinical } \\
\text { synovitis and tenosynovitis [25] }\end{array}$ \\
\hline & & $\begin{array}{l}\text { Operator must be familiar with } \\
\text { imaging artifacts that can cause } \\
\text { misinterpretation or be mistaken } \\
\text { for pathology }[50,51]\end{array}$ & $\begin{array}{l}\text { Measurement of abnormal } \\
\text { vascularization (indicator of } \\
\text { active inflammation) [31] } \\
\text { Differentiation of subclinical } \\
\text { enthesitis [14] }\end{array}$ \\
\hline
\end{tabular}


Table 1 continued

\begin{tabular}{|c|c|c|c|}
\hline $\begin{array}{l}\text { Imaging } \\
\text { technique }\end{array}$ & Strengths & Weaknesses & Preferred use \\
\hline \multirow[t]{3}{*}{ MRI } & Nonionizing and noninvasive [63] & $\begin{array}{l}\text { Substantially higher cost and lower } \\
\text { availability; long length of time } \\
\text { to perform scan [26] }\end{array}$ & Assessment of preclinical PsA [38] \\
\hline & $\begin{array}{l}\text { Muscles, ligaments, and tendons } \\
\text { are seen much more clearly than } \\
\text { on X-rays [63] }\end{array}$ & $\begin{array}{l}\text { Potential for toxicity (use of } \\
\text { gadolinium-containing contrast } \\
\text { agents) }[81]\end{array}$ & $\begin{array}{l}\text { Assessment of axial involvement } \\
\text { and active inflammatory changes } \\
\text { and soft tissue abnormalities } \\
\text { (thickening of tendons and } \\
\text { ligaments, joint effusions and } \\
\text { inflammation, bone erosions, } \\
\text { enthesophytes, and intraosseous } \\
\text { bone marrow edema associated } \\
\text { with enthesitis and sacroiliitis) } \\
{[14]}\end{array}$ \\
\hline & $\begin{array}{l}\text { Can monitor therapeutic response } \\
{[63]}\end{array}$ & & $\begin{array}{l}\text { Visualization of small, active } \\
\text { inflammatory changes and } \\
\text { lesions that are present early in } \\
\text { the disease course }[53,54]\end{array}$ \\
\hline
\end{tabular}

and/or new bone formation, which tend to be seen in later stages of the disease, and can help visualize soft tissue swelling suggestive of dactylitis (Fig. 1) [12, 22].

Patients with PsA most frequently have structural changes in the hands and feet, but other joints may also be affected [11]. Typical radiographic changes include fluffy periostitis, joint damage (e.g., joint space narrowing, erosions, osteolysis, subluxation, ankylosis, pencilin-cup deformity), and new bone formation (e.g., enthesophytes) (Table 2) [23].

The main advantages of plain radiography are its low cost and availability. Additionally, plain radiography can determine involvement of the sacroiliac joint and joints of the spine, including entheseal new bone formation [24]. These changes, which are seen in more advanced disease, are not readily imaged using other techniques such as ultrasound, which cannot penetrate the bone surface [25]. However, plain radiography has limited utility in assessing the early soft-tissue changes seen in
PsA [13, 26], especially axial changes [27]. Radiographs taken during this stage of the disease can appear normal, resulting in a significant delay in diagnosis if other imaging modalities are not used. Ultrasound and MRI are generally preferred to conventional radiography for identifying early signs of inflammatory arthritis and changes in musculoskeletal structures.

\section{Ultrasound}

Ultrasound displays the structures and compositions of different tissues based on their echogenicity (Table 2) [28-30]. Structures can be characterized as anechoic (transmit sound waves; black image), hyperechoic (greatly reflect signal; bright/white image), or hypoechoic (reflect and transmit sound waves; darker gray image) (Table 2). Soft tissue results in images in varying shades of gray; tissues leading to brighter images compared to their surroundings are considered hyperechoic, and those leading 

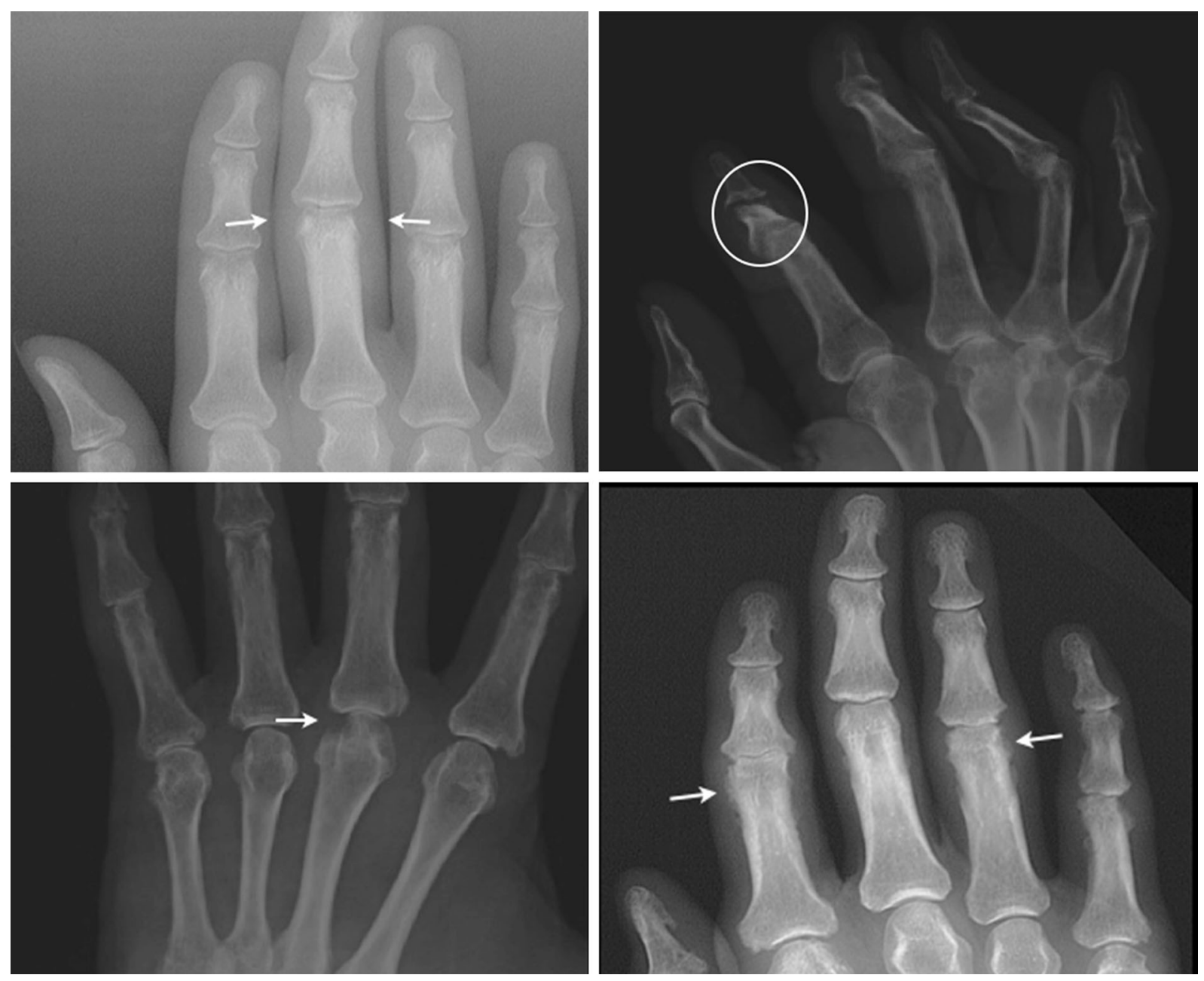

Fig. 1 X-ray imaging of structural changes in patients with PsA. Clockwise from top left: diffuse soft tissue swelling (sausage digit); destruction and widening of the joint space; bone production (periostitis); and marginal bone

to darker images are considered hypoechoic (Fig. 2).

Structures at different depths can be assessed using different ultrasound frequencies [28, 29]. Superficial structures can be visualized using high frequencies $(>12 \mathrm{MHz})$, which have shorter wavelengths and less penetration but provide higher resolution; low frequencies ( $\leq 12 \mathrm{MHz}$ ) have longer wavelengths and can be used to visualize deeper body structures but with poorer resolution.

Ultrasound can be used to produce 2D grayscale images, and a series of $2 \mathrm{D}$ images can be combined to make a 3D image [29]. In

erosion. Ps $A$ psoriatic arthritis Batlle JA, et al. Presented at the European Congress of Radiology 2011, poster C-0065 (copyright (C): 2001-2018 European Congress of Radiology, 2005-2018 European Society of Radiology)

addition, Doppler ultrasound can be used to visualize movement, such as blood in vessels, and to screen patients for abnormal vascularization, which is indicative of active inflammation [31-33]. Common Doppler techniques used in rheumatology include color Doppler, which is used to determine the direction and mean velocity of blood flow, and power Doppler, which has higher sensitivity to blood flow but does not provide the flow direction [34, 35]. Doppler ultrasound can be used to enhance conventional ultrasound, as the ability to identify even minimal abnormal vascularization is important for the detection of subclinical 
Table 2 Glossary of technical terms used in clinical imaging study reports

\section{Term}

Absorption

Anechoic

Anisotropy

Ankylosis

Attenuation

Contrast

Contrast agent

Dactylitis

Echogenicity

Enthesis

Enthesitis

Enthesopathy

Enthesophyte

Erosion

Gadolinium (Gd)

Hyperechoic

Hypoechoic

Isoechoic

Joint space narrowing (JSN)

Juxta-articular osteopenia

Luxation

Osteolysis

Osteophyte

Osteoproliferation

\section{Definition}

Reduction in sound wave intensity as it passes through tissue, with energy lost in the form of heat

Without an echo; images appear black

Artifact is dependent on the angle of the ultrasound beam, which may result in an incorrect diagnosis; dramatic changes in reflection result from small changes in the angle of incidence of the transducer; notably observed in muscles and tendons

Abnormal joint stiffening and immobility resulting from fusion of bones

Sound waves become weaker and lose energy during deeper travel within the body; composed of three processes: reflection, absorption, and refraction

Difference in signal intensity divided by the average signal intensity of two adjacent regions

Substance given to a patient to alter the image intensity of a particular body region

Diffuse soft tissue thickening/inflammation in the fingers and toes, i.e., "sausage digit" (associated with synovitis, tenosynovitis, and enthesitis)

Ability to return the signal back to the transducer (an echo)

Connective tissue between bone and either a tendon or ligament

Inflammation of the entheses

Presence of either the combination of at least abnormal thickening and hypoechogenicity of the tendon insertion with or without the presence of a Doppler signal (grade 0-3) or $\geq 2$ Doppler signals alone with or without abnormal thickening and hypoechogenicity

Abnormal bony projection at the attachment of a tendon or ligament

Gradual destruction and loss of bone in a particular area

Paramagnetic contrast agent that strongly shortens T1; very bright on T1W images and especially useful for observing vascular structures; given in chelated form, as it is toxic by itself

More echogenic (increased density of echoes) than surrounding tissues and appears lighter

Less echogenic (fewer echoes) than surrounding tissues and appears darker

Same echogenicity as surrounding tissue and indistinguishable in color

Narrowing of the joint space between the bones, resulting in a change in the joint's range of motion

Loss of bone mass near a joint

Complete separation of the joints

Progressive destruction of bony tissue through active resorption of bone matrix by osteoclasts (multinucleated bone cells)

Abnormal bony projection along the edge of bone, often forming in joints

Growth (proliferation) of bone tissue 
Table 2 continued

\begin{tabular}{|c|c|}
\hline Term & Definition \\
\hline Pencil-in-cup deformity & $\begin{array}{l}\text { Periarticular (around the joint) erosions and bone resorption leading to a sharpened pencil } \\
\text { shape }\end{array}$ \\
\hline Periosteum & Tissue surrounding bone \\
\hline Periostitis & Inflammation of the periosteum \\
\hline Reflection & $\begin{array}{l}\text { Sound wave passes between two tissues of different acoustic speeds, with a portion of the } \\
\text { waves returning to the transducer }\end{array}$ \\
\hline Refraction & $\begin{array}{l}\text { Sound waves are deflected away from the straight path with an angle of deflection away from } \\
\text { the transducer }\end{array}$ \\
\hline Repetition time (TR) & Time between successive pulse sequences applied to the same slice \\
\hline Sacroiliac joint & $\begin{array}{l}\text { Joint that connects the hip bones to the sacrum (triangular bone between the lumbar spine } \\
\text { and tailbone) }\end{array}$ \\
\hline Sacroiliitis & Inflammation of the sacroiliac joints \\
\hline Sclerosis & Unusual hardening or thickening of bone \\
\hline $\begin{array}{l}\text { Short-tau inversion } \\
\text { recovery (STIR) }\end{array}$ & $\begin{array}{l}\text { Used to suppress the signal from fat, or more specifically tissues with } \mathrm{T} 1 \text { values in the range of } \\
\text { fat; cannot be used as a fat suppression technique following gadolinium administration }\end{array}$ \\
\hline Subluxation & Connecting bone is partially out of the joint but can often return to normal position \\
\hline T1 & $\begin{array}{l}\text { Spin-lattice relaxation time; measure of the time taken for spinning protons to realign with } \\
\text { the external magnetic field }\end{array}$ \\
\hline T1-weighted (T1W) & $\begin{array}{l}\text { Image where most of the contrast between tissues is due to differences in tissue T1; fatty } \\
\text { tissues appear bright while fluid appears black; produced by using a short echo time (TE) } \\
\text { and TR }\end{array}$ \\
\hline $\mathrm{T} 2$ & $\begin{array}{l}\text { Spin-spin relaxation time; measure of the time taken for spinning protons to lose phase } \\
\text { coherence among nuclei spinning perpendicular to the main field }\end{array}$ \\
\hline T2-weighted (T2W) & $\begin{array}{l}\text { Image where most of the contrast between tissues is due to differences in tissue T2; both fatty } \\
\text { and water-based tissues appear bright; fatty tissue is distinguishable from water-based tissue } \\
\text { through comparison with T1W images; produced by using a longer TE and TR than T1W }\end{array}$ \\
\hline Transmission & $\begin{array}{l}\text { Sound waves continue traveling deeper into the body and are not reflected initially but can be } \\
\text { reflected by deeper tissue structures }\end{array}$ \\
\hline
\end{tabular}

inflammation, though additional training may be needed for its use [34, 35].

Key features of PsA that are detected by ultrasonography include enthesitis and synovitis $[36,37]$. Enthesitis, a hallmark of PsA that is believed to be the first sign of disease, has a prevalence of $20 \%$ in patients with psoriasis by clinical exam $[15,37]$. However, the proportion of patients with enthesitis by ultrasound or MRI is much higher. Studies using advanced musculoskeletal imaging techniques have shown that up to half of patients with psoriasis may exhibit inflammatory and structural abnormalities in their joints and entheses, which can precede and even help predict the onset of PsA $[38,39]$. Enthesitis is common in the tendons 

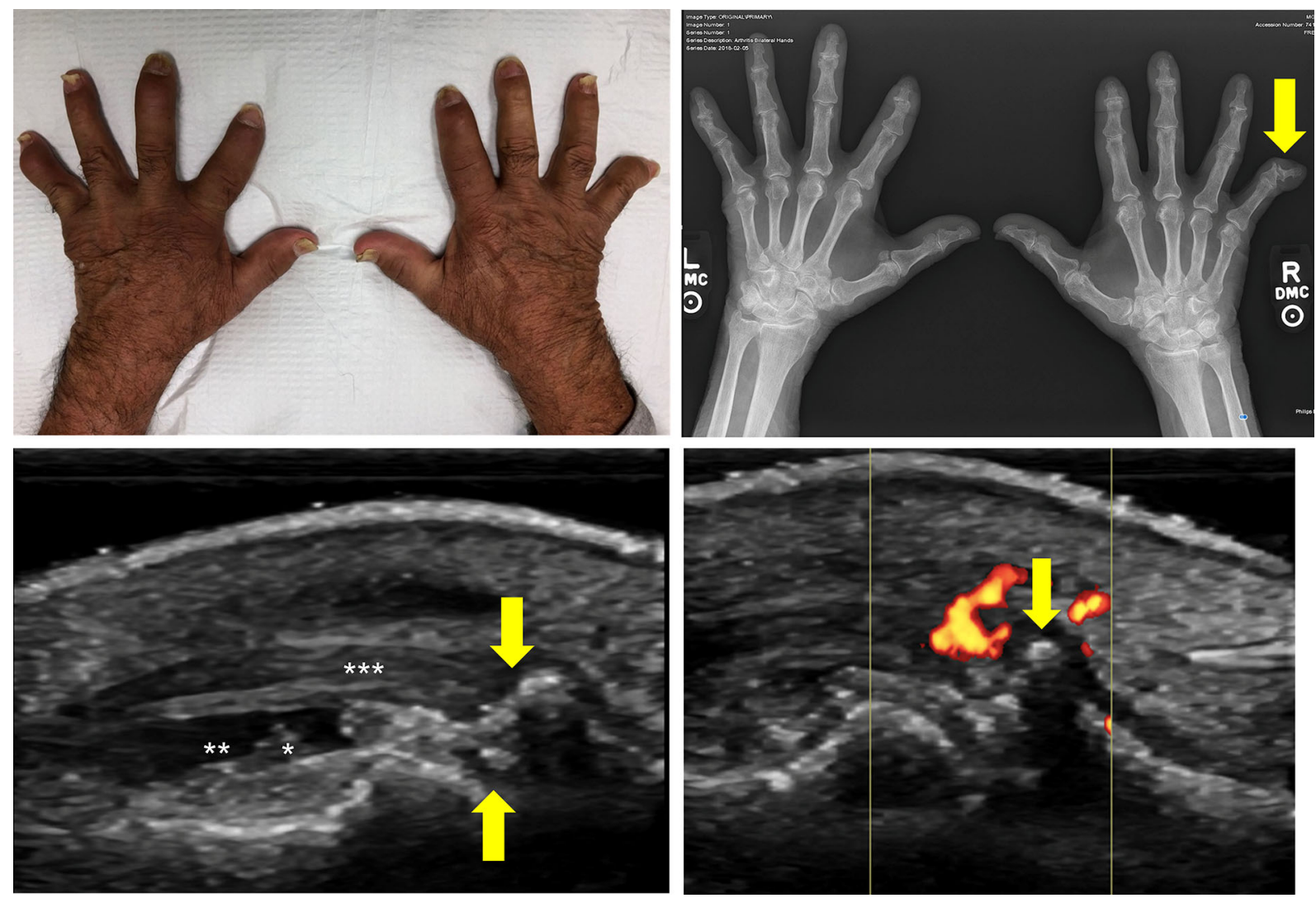

Fig. 2 Clinical, radiographic, and ultrasound assessments in a patient with PsA. Top left: nail changes, dactylitis, and DIP subluxation as seen during clinical examination. Top right: conventional radiographs of the same patient exhibiting "wispy periostitis" and DIP subluxation (indicated by the arrow). Bottom left: ultrasound providing a longitudinal view of the DIP extensor tendon (indicated by the triple asterisk) showing enthesitis in the hand (extensive cortical irregularity indicated by the downward

and fasciae of the extremities [40] and is characterized by tendon thickening and hypoechogenicity at the entheses (Fig. 3) [31, 41]. Multiple scoring systems, such as those from the Outcome Measures in Rheumatology (OMERACT) Ultrasound Working Group [41] and the Group for Research and Assessment of Psoriasis and Psoriatic Arthritis (GRAPPA) Ultrasound Working Group [31], have been devised to aid in identifying enthesitis by ultrasound [13]. Synovitis can also be detected by ultrasound in almost one-third of patients with psoriasis, despite these patients showing

arrow; DIP joint indicated by the upward arrow) as well as synovial effusion at the DIP joint (indicated by the double asterisk) and synovial hypertrophy (single asterisk). Bottom right: power Doppler ultrasound showing the same area of damage, with the Doppler signal indicating active inflammation around the cortical irregularity. DIP distal interphalangeal joint, $P_{s} A$ psoriatic arthritis. Reprinted with permission from The Journal of Rheumatology, Bakewell et al. [13]. All rights reserved

no musculoskeletal symptoms [37]. Ultrasound can also help identify patients with or without arthralgia who may be in a transitional phase of PsA-in these patients, tenosynovitis, synovitis, and enthesitis have been associated with arthralgia $[16,42]$.

Overall, ultrasound has many advantages. It is portable, less expensive than MRI, very low risk due to its nonionizing and noninvasive nature, and readily available, allowing for realtime dynamic imaging by healthcare providers, including dermatologists [26, 43]. Imaging of multiple joints/entheses, including upper and 

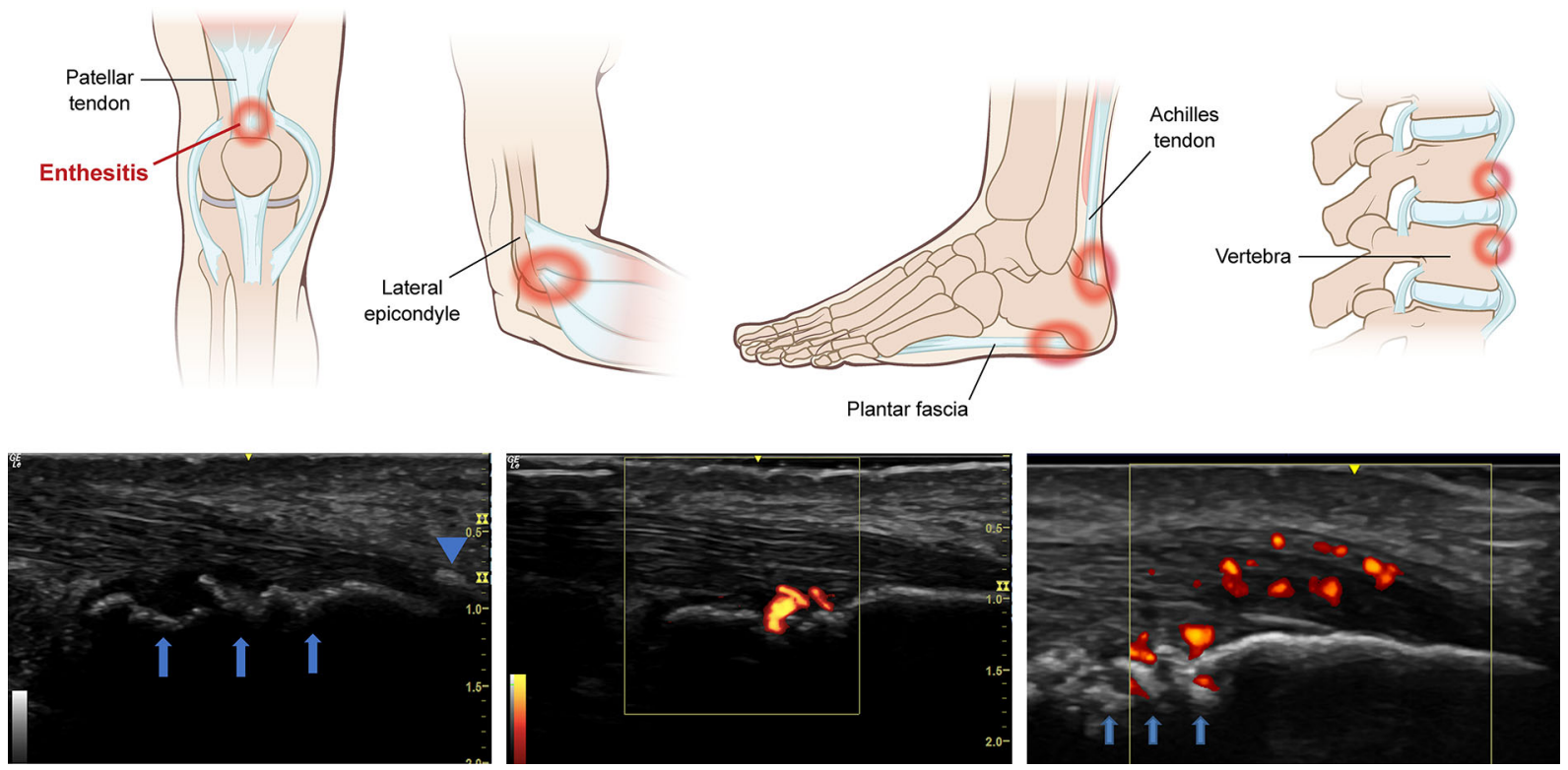

Fig. 3 Imaging of entheses by ultrasound. Top: entheseal structures. Bottom left and center: ultrasound (left) and ultrasound with Doppler images (center) of the right Achilles tendon of a patient with PsA experiencing no tenderness on clinical examination. Visualized changes include erosion/cortical irregularities (arrows) and distal

lower extremity entheses, can be performed, allowing for contralateral comparison [44]. Doppler ultrasound can measure blood flow, which has been shown to correspond with the level of inflammation [31] and subsequent structural damage $[45,46]$. Ultrasound can therefore identify patients with early PsA, allowing for earlier treatment.

However, because ultrasound waves cannot penetrate the bone surface, this technique is limited in the three-dimensional assessment of osseous structures or when evaluation of bone marrow edema (BME) is critical, such as when assessing inflammation or structural changes of the axial skeleton [47]. Thus, MRI is likely to remain the gold standard for imaging axial disease. Although the small number of blood vessels in entheses and artifacts due to the proximity to bone may also hinder ultrasound assessments in some cases, ultrasound is largely superior to MRI for generating higher-resolution images of entheses [32, 48, 49]. Another consideration is that the ultrasound examiner must be knowledgeable about imaging artifacts enthesophyte (arrowhead). Bottom right: Achilles heel with Doppler signal within calcaneal erosion, indicating current activity and Achilles intrasubstance hypoechogenicity/ thickening. Arrows indicate proximal erosions in the calcaneus. $P s A$ psoriatic arthritis

that can frequently occur. These artifacts can cause visualization of nonexistent structures or nonvisualization of existent structures and can also alter size, location, and brightness; this can lead to misinterpretation of results or mimic pathology in normal structures [50]. For example, fibrillary linear structures such as tendons or ligaments can appear hypoechoic if the ultrasound beam is not perpendicular during visualization; this could be misinterpreted as tendonitis or tears [51]. Proper training and awareness of artifacts can avoid such misinterpretations.

\section{MRI}

MRI is noninvasive and nonionizing and can be used to visualize inflammation in soft tissues and bone (Fig. 4) [14]. Different pulse sequences (e.g., T1-weighted [T1W] vs T2-weighted [T2W]) can change the image contrasts to visualize various structures (fat vs water sensitive, respectively); short-tau inversion recovery (STIR) sequences, which suppress signals from 

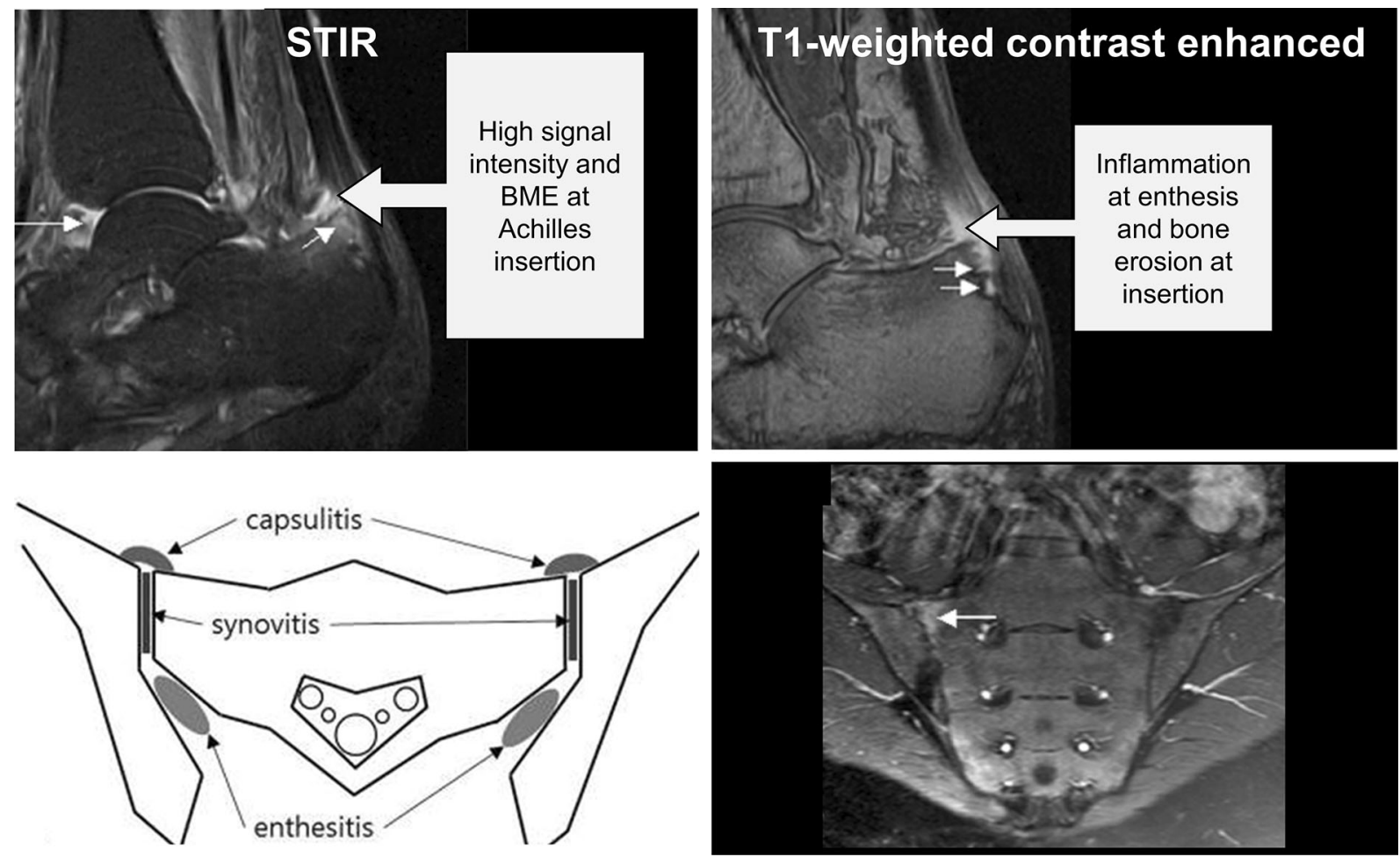

Fig. 4 Imaging of entheses by MRI. Top: soft tissues of the entheses visualized by MRI. Bottom left: enthesitis, synovitis, and capsulitis in sacroiliac joint. Bottom right: T1weighted semicoronal MRIs through the sacroiliac joints after intravenous contrast injection. Enhancement is seen at the right sacroiliac joint (arrow), indicating active sacroiliitis. BME bone marrow edema, MRI magnetic

resonance imaging, STIR short-tau inversion recovery Reprinted by permission from McQueen F, et al. Arthritis Res Ther. 2006;8(2):207 (copyright (C) 2006, Springer Nature) and from Sung S, et al. Br J Radiol. 2017; 90(1078):20170090 (C) 2017 British Institute of Radiology)

fat, can be used to visualize BME, synovitis, and tenosynovitis. Imaging performed before and after the administration of a contrast agent, most commonly gadolinium, can aid in confirming and pinpointing inflammation and detecting structural pathologies.

The sensitivity of MRI allows the visualization of small, active inflammatory changes and lesions that are present early in the disease course [13, 52]. MRI can be used to detect axial or peripheral enthesitis and, like ultrasound, can detect early signs of enthesitis and inflammatory lesions that are not detectable by radiography [53, 54]. Lesions evident by MRI include thickening of tendons and ligaments, joint effusions and inflammation, bone

erosions, enthesophytes, and intraosseous BME $[27,52]$.

MRI is particularly helpful in the early diagnosis of axial PsA, given its ability to detect inflammatory and structural lesions [27], and can aid in distinguishing axial PsA from ankylosing spondylitis or nonradiographic axial spondyloarthritis; patients with the latter do not show radiographic evidence of sacroiliitis but often show BME by MRI [55]. Although using inflammatory changes visible by MRI alone to diagnose axial spondyloarthritis could result in false positives [56], structural lesions in sacroiliac joints (e.g., erosions) are more specific for the presence of spinal inflammatory disease, even in the absence of sacroiliac joint BME on 
MRI [57]. Imaging of active inflammation (i.e., synovitis, enthesitis) in the sacroiliac joints is best done with a postintravenous $\mathrm{T} 1$ gadolinium sequence or fat-suppressed T2W or STIR sequence [58, 59]. Changes associated with chronic inflammation, including fat deposition and erosions, can be detected by using a T1W sequence. For a more extensive assessment of axial disease, lumbar and/or cervical MRI can be performed [59].

Like ultrasound, MRI can help identify patients with subclinical or early PsA. In a study in patients with psoriasis without PsA, MRI revealed that approximately half of the patients had $\geq 1$ inflammatory lesion, with synovitis being the most prevalent [38]. Subclinical inflammatory lesions in patients with arthralgia were associated with a higher risk of developing PsA. Similar findings were seen in the IVEPSA study in patients with psoriasis with inflammatory arthralgia; $83 \%$ had $\geq 1$ inflammatory lesion, with synovitis and tenosynovitis being the most prevalent [60]. MRI scoring systems have been developed to aid in the diagnosis of PsA. The Psoriatic Arthritis Magnetic Resonance Imaging Score (PsAMRIS) has been developed specifically for PsA in the hands and feet and includes measures of synovitis, tenosynovitis, periarticular inflammation, BME, bone erosion, and bone proliferation [61-63]. The Heel Enthesitis MRI Scoring System measures both structural and inflammatory changes, including heel enthesitis [64].

Unlike radiography and ultrasound, MRI is costly, not readily available, and contraindicated in patients with pacemakers or ferromagnetic metal implants [13, 27]. Another disadvantage of MRI is that only a single body area can be imaged in one scan; however, whole-body multijoint MRI is being developed $[13,65]$. This technique allows the assessment of entheses and all peripheral and axial joints as well as the distribution of inflammation and structural damage in the entire body in one examination. The MRI Whole-Body Score for Inflammation in Peripheral Joints and Entheses has been developed and continues to be validated in clinical trials and longitudinal studies; however, limitations include a lack of assessment of structural damage in hands and feet and the fact that few sites worldwide are able to perform these scans in a reasonable amount of time [66].

\section{Other Imaging Modalities}

Other imaging techniques that are used to assess patients with PsA include computed tomography (CT) and bone scintigraphy. The accuracy of CT is comparable to that of MRI for assessing erosions in the sacroiliac joint $[23,67]$. Although standard-resolution CT has limited ability to detect synovial inflammation in peripheral joints, dual-energy CT iodine mapping has shown promise in detecting inflammatory lesions in distal interphalangeal joints $[68,69]$, while positron emission tomography/ CT using ${ }^{18}$ F-fluorodeoxyglucose has shown high sensitivity for evaluating enthesitis in patients with spondyloarthritis [70].

Bone scintigraphy uses radiolabeled phosphate analogues to identify active bone remodeling and increased vascularization indicative of inflammation [71]. It is highly sensitive and can detect both axial and peripheral arthritis and enthesitis, including subclinical involvement in patients with psoriasis without clinical arthropathy [72-75]. However, bone scintigraphy is less specific than ultrasound and MRI [23], but it may be useful as a complementary tool for characterizing patients with arthritis or for evaluating the extent of peripheral involvement in patients with limited clinical evidence of peripheral arthritis [71, 73-75].

\section{Imaging in Patient Management}

In addition to identifying signs of PsA, these imaging modalities can be used by dermatologists to monitor a patient's response to treatment. Radiographs can be used to assess response to therapy in clinical trials, and various scoring systems have been developed to assess radiographic progression; the most commonly used is the Sharp-van der Heijde scoring method for PsA [12, 21]. Radiographic damage in clinical trials is assessed by two or three readers to ensure reliability, and a mean change 
of $\leq 0.5$ in total score (vs 0 ) is usually used to determine the absence of radiographic progression [76]. Several studies have used radiography to show that biologics have the ability to inhibit radiographic progression-an important treatment goal-in patients with PsA [12]. On the basis of these findings, rheumatologists can use radiographs to measure the extent and progression of damage as well as bone erosions and joint space narrowing at baseline in patients with PsA, and to determine the best treatment options for them.

Similarly, ultrasound and MRI have been used to monitor the effect of treatment in patients with subclinical signs of PsA. A 6-month prospective study followed the evolution of enthesitis under systemic treatment with methotrexate and/or biologics (adalimumab, infliximab, ustekinumab). Among 13 patients with psoriasis who had ultrasound assessments at baseline and 6 months, the proportion of morphological abnormalities in entheses significantly decreased from $30.0 \%$ to $17.7 \%$ [77]. More recently, a pilot study in 23 patients with moderate to severe psoriasis without symptoms of PsA who fulfilled the OMERACT definition of enthesopathy by ultrasound and were treated with ustekinumab showed that mean entheseal inflammation scores decreased by $42.2 \%$ and $47.5 \%$ from baseline to weeks 24 and 52, respectively [15]. In the IVEPSA study, patients with psoriasis, no clinical PsA, and inflammatory or erosive changes by MRI or CT were treated with the interleukin 17A inhibitor secukinumab over 24 weeks [60]. Total PsAMRIS and synovitis subscores significantly improved and erosions and enthesophytes did not progress, suggesting that progression of subclinical PsA can be prevented by secukinumab treatment and its status monitored using MRI [60]. However, MRI is not commonly used in clinical practice to monitor disease progression.

These studies highlight the substantial role that imaging plays in the management of PsA. Although the use of imaging is more common in the rheumatology setting, understanding common imaging techniques can better equip dermatologists to identify patients with signs of PsA, including those with preclinical PsA. Given that approximately half of patients with psoriasis may have subclinical signs of PsA, incorporating imaging into future screening and treatment algorithms in dermatology settings may help with earlier referral to rheumatologists and diagnosis of PsA, resulting in optimal treatment of patients. More research is needed on the role of imaging in PsA. Recommendations by an international task force on the assessment of disease activity included clinical signs and symptoms and acute phase reactants, but not imaging, due to a lack of data on its use [78]. However, this task force also added a new recommendation that, in addition to clinical and laboratory measures, imaging may be considered in clinical management, noting that imaging could be used to assess if a therapeutic target had been reached, although it is not recommended as a target itself [78].

\section{SUMMARY}

Dermatologists play a critical role in the diagnosis of PsA in patients with psoriasis and are therefore strongly encouraged to routinely screen their patients for signs of PsA. The specific role will vary depending on the level of involvement and motivation of the dermatologist, but all are important. For example, there may be dermatologists who are deeply motivated and interested in using musculoskeletal ultrasound for screening in-office. At a more intermediate level, there may be a wider group of dermatologists who know when to order and interpret musculoskeletal imaging to support their clinical diagnosis and clinical decision making. Finally, dermatologists with a highlevel understanding of the tools that are being used by rheumatologists and others to support their diagnosis of PsA can use this information in their decision making to potentially interpret reports about the use of imaging from radiology and those rheumatology providers. Early diagnosis and appropriate treatment of patients with PsA can prevent or delay joint damage and its associated negative outcomes. Along with clinical assessments, musculoskeletal imaging serves as a tool that can help physicians identify signs of clinical and subclinical PsA, which may be particularly relevant for patients with severe 
psoriasis, nail pitting, uveitis, axial involvement, or other nonspecific musculoskeletal symptoms. Having even a basic understanding of the main imaging modalities used in the management of patients with PsA will enhance collaboration between dermatologists and rheumatologists in the shared management of patients with PsA and greatly benefit both patients and physicians.

\section{ACKNOWLEDGEMENTS}

Funding. Support for third-party writing assistance and the Rapid Service Fee were funded by Novartis Pharmaceuticals Corporation, East Hanover, NJ.

Authorship. All named authors meet the International Committee of Medical Journal Editors (ICMJE) criteria for authorship for this article, take responsibility for the integrity of the work as a whole, and have given their approval for this version to be published.

Author contributions. A. B. Gottlieb, C. Bakewell, and J. F. Merola meet the International Committee of Medical Journal Editors (ICMJE) criteria for authorship for this article, were involved in conceptualization of the review and preparing/critically reviewing all drafts, take responsibility for the integrity of the work as a whole, and have given their approval for this version to be published.

Medical writing, editorial, and other assistance. The authors thank Karen Chinchilla, PhD, CMPP, of ArticulateScience LLC (Hamilton, NJ), and Elizabeth Ohneck, $\mathrm{PhD}$, of Health Interactions, Inc (Hamilton, $\mathrm{NJ}$ ), both of Nucleus Global, for providing medical writing and editorial support, which was funded by Novartis Pharmaceuticals Corporation (East Hanover, NJ) in accordance with Good Publication Practice (GPP3) guidelines (http:// www.ismpp.org/gpp3).

Disclosures. Alice B. Gottlieb has served as a consultant and/or advisory board member for
AnaptysBio, Avotres, Beiersdorf, Boehringer Ingelheim, Bristol Myers Squibb, Incyte, LEO Pharma, Lilly, Novartis, Sun Pharma, UCB, Janssen, and XBiotech. She has also received research or educational grants from Boehringer Ingelheim, Janssen, Novartis, UCB, and XBiotech (all research and educational grants go to Mount Sinai Medical School). Catherine Bakewell has received consultancy fees from and/or served on speakers bureaus for AbbVie, Sanofi/ Genzyme, Pfizer, Janssen, UCB, and Novartis. Joseph F. Merola is a consultant and/or investigator for Merck, Bristol Myers Squibb, AbbVie, Dermavant, Eli Lilly, Novartis, Janssen, UCB, Sanofi, Regeneron, Arena, Sun Pharma, Biogen, Pfizer, EMD Serono, Avotres, and LEO Pharma.

Data availability. Data sharing is not applicable to this article as no datasets were generated or analyzed during the current study.

Compliance with ethics guidelines. This article is based on previously conducted studies and does not contain any new studies with human participants or animals performed by any of the authors.

Open Access. This article is licensed under a Creative Commons Attribution-NonCommercial 4.0 International License, which permits any non-commercial use, sharing, adaptation, distribution and reproduction in any medium or format, as long as you give appropriate credit to the original author(s) and the source, provide a link to the Creative Commons licence, and indicate if changes were made. The images or other third party material in this article are included in the article's Creative Commons licence, unless indicated otherwise in a credit line to the material. If material is not included in the article's Creative Commons licence and your intended use is not permitted by statutory regulation or exceeds the permitted use, you will need to obtain permission directly from the copyright holder. To view a copy of this licence, visit http://creativecommons.org/licenses/bync/4.0/. 


\section{REFERENCES}

1. Elmets CA, Leonardi CL, Davis DMR, Gelfand JM, Lichten J, Mehta NN, et al. Joint AAD-NPF guidelines of care for the management and treatment of psoriasis with awareness and attention to comorbidities. J Am Acad Dermatol. 2019;80(4):1073-113. https://doi.org/10.1016/j.jaad.2018.11.058.

2. Alinaghi F, Calov M, Kristensen LE, Gladman DD, Coates LC, Jullien D, et al. Prevalence of psoriatic arthritis in patients with psoriasis: a systematic review and meta-analysis of observational and clinical studies. J Am Acad Dermatol. 2019;80(1): 251-65.e219. https://doi.org/10.1016/j.jaad.2018. 06.027 .

3. Coates LC, Helliwell PS. Psoriatic arthritis: state of the art review. Clin Med (Lond). 2017;17(1):65-70. https://doi.org/10.7861/clinmedicine.17-1-65.

4. Haroon M, Gallagher P, FitzGerald O. Diagnostic delay of more than 6 months contributes to poor radiographic and functional outcome in psoriatic arthritis. Ann Rheum Dis. 2015;74(6):1045-50. https://doi.org/10.1136/annrheumdis-2013204858.

5. Gladman DD, Antoni C, Mease P, Clegg DO, Nash P. Psoriatic arthritis: epidemiology, clinical features, course, and outcome. Ann Rheum Dis. 2005;64(suppl 2):14-7.

6. Yang Q, Qu L, Tian H, Hu Y, Peng J, Yu X, et al. Prevalence and characteristics of psoriatic arthritis in Chinese patients with psoriasis. J Eur Acad Dermatol Venereol. 2011;25(12):1409-14. https://doi. org/10.1111/j.1468-3083.2011.03985.x.

7. Mease PJ, Gladman DD, Papp KA, Khraishi MM, Thaci D, Behrens F, et al. Prevalence of rheumatologist-diagnosed psoriatic arthritis in patients with psoriasis in European/North American dermatology clinics. J Am Acad Dermatol. 2013;69(5):729-35. https://doi.org/10.1016/j.jaad.2013.07.023.

8. Coates LC, Savage L, Waxman R, Moverley AR, Worthington S, Helliwell PS. Comparison of screening questionnaires to identify psoriatic arthritis in a primary-care population: a cross-sectional study. Br J Dermatol. 2016;175(3):542-8. https://doi.org/10.1111/bjd.14604.

9. Iragorri N, Hazlewood G, Manns B, Danthurebandara V, Spackman E. Psoriatic arthritis screening: a systematic review and meta-analysis. Rheumatol (Oxf). 2019;58(4):692-707. https://doi.org/10. 1093/rheumatology/key314.

10. Cohen JM, Husni ME, Qureshi AA, Merola JF. Psoriatic arthritis: it's as easy as "PSA." J Am Acad
Dermatol. 2015;72(5):905-6. https://doi.org/10. 1016/j.jaad.2014.12.008.

11. Wassenberg S. Radiographic scoring methods in psoriatic arthritis. Clin Exp Rheumatol. 2015;33(5 suppl 93):S55-9.

12. van der Heijde D, Gladman DD, Kavanaugh A, Mease PJ. Assessing structural damage progression in psoriatic arthritis and its role as an outcome in research. Arthritis Res Ther. 2020;22(1):18. https:// doi.org/10.1186/s13075-020-2103-8.

13. Bakewell C, Aydin SZ, Ranganath VK, Eder L, Kaeley GS. Imaging techniques: options for the diagnosis and monitoring of treatment of enthesitis in psoriatic arthritis. J Rheumatol. 2020;47(7):973-82. https://doi.org/10.3899/jrheum.190512.

14. Baraliakos $\mathrm{X}$, Conaghan PG, D'Agostino MA, Maksymowych W, Naredo E, Ostergaard M, et al. Imaging in rheumatoid arthritis, psoriatic arthritis, axial spondyloarthritis, and osteoarthritis: an international viewpoint on the current knowledge and future research priorities. Eur J Rheumatol. 2019;6(1):38-47. eurjrheum.2018.18121.

15. Savage L, Goodfield M, Horton L, Watad A, Hensor E, Emery P, et al. Regression of peripheral subclinical enthesopathy in therapy-naive patients treated with ustekinumab for moderate-to-severe chronic plaque psoriasis: a fifty-two-week, prospective, open-label feasibility study. Arthritis Rheumatol. 2019;71(4):626-31. https://doi.org/10.1002/art. 40778.

16. Eder L, Polachek A, Rosen CF, Chandran V, Cook R, Gladman DD. The development of psoriatic arthritis in patients with psoriasis is preceded by a period of nonspecific musculoskeletal symptoms: a prospective cohort study. Arthritis Rheumatol. 2017;69(3):622-9. https://doi.org/10.1002/art. 39973.

17. Eder L, Haddad A, Rosen CF, Lee KA, Chandran V, Cook $\mathrm{R}$, et al. The incidence and risk factors for psoriatic arthritis in patients with psoriasis: a prospective cohort study. Arthritis Rheumatol. 2016;68(4):915-23. https://doi.org/10.1002/art. 39494.

18. Haroon M, Winchester R, Giles JT, Heffernan E, FitzGerald $\mathrm{O}$. Clinical and genetic associations of radiographic sacroiliitis and its different patterns in psoriatic arthritis. Clin Exp Rheumatol. 2017;35(2): 270-6.

19. Braga MV, de Oliveira SC, Vasconcelos AHC, Lopes JR, de Macedo Filho CL, Ramos LMA, et al. Prevalence of sacroiliitis and acute and structural changes on MRI in patients with psoriatic arthritis. Sci 
Rep. 2020;10(1):11580. https://doi.org/10.1038/ s41598-020-68456-7.

20. Felbo SK, Terslev L, Østergaard M. Imaging in peripheral and axial psoriatic arthritis: contributions to diagnosis, follow-up, prognosis and knowledge of pathogenesis. Clin Exp Rheumatol. 2018;36(5):24-34.

21. Ory PA. Radiography in the assessment of musculoskeletal conditions. Best Pract Res Clin Rheumatol. 2003;17(3):495-512. https://doi.org/10.1016/ s1521-6942(03)00022-6.

22. Kaeley GS, Eder L, Aydin SZ, Gutierrez M, Bakewell C. Dactylitis: a hallmark of psoriatic arthritis. Semin Arthritis Rheum. 2018;48(2):263-73. https://doi. org/10.1016/j.semarthrit.2018.02.002.

23. Ory PA, Gladman DD, Mease PJ. Psoriatic arthritis and imaging. Ann Rheum Dis. 2005;64(Suppl 2): 55-7. https://doi.org/10.1002/art.21306.

24. Watad A, Eshed I, McGonagle D. Lessons learned from imaging on enthesitis in psoriatic arthritis. Isr Med Assoc J. 2017;19(11):708-11.

25. Kaeley GS, Bakewell C, Deodhar A. The importance of ultrasound in identifying and differentiating patients with early inflammatory arthritis: a narrative review. Arthritis Res Ther. 2020;22(1):1. https://doi.org/10.1186/s13075-019-2050-4.

26. Kaeley GS, Eder L, Aydin SZ, Gutierrez M, Bakewell C. Enthesitis: a hallmark of psoriatic arthritis. Semin Arthritis Rheum. 2018;48(1):35-53. https:// doi.org/10.1016/j.semarthrit.2017.12.008.

27. Khmelinskii N, Regel A, Baraliakos X. The role of imaging in diagnosing axial spondyloarthritis. Front Med (Lausanne). 2018;5:106. https://doi.org/ 10.3389/fmed.2018.00106.

28. Ihnatsenka B, Boezaart AP. Ultrasound: Basic understanding and learning the language. Int $\mathrm{J}$ Shoulder Surg. 2010;4(3):55-62. https://doi.org/10. 4103/0973-6042.76960.

29. Carovac A, Smajlovic F, Junuzovic D. Application of ultrasound in medicine. Acta Inform Med. 2011;19(3):168-71. https://doi.org/10.5455/aim. 2011.19.168-171.

30. Barcaui EEO, Carvalho AC, Lopes FP, Piñeiro-Maceira J, Barcaui CB. High frequency ultrasound with color Doppler in dermatology. An Bras Dermatol. 2016;91(3):262-73. https://doi.org/10.1590/ abd1806-4841.20164446.

31. Tom S, Zhong Y, Cook R, Aydin SZ, Kaeley G, Eder L. Development of a preliminary ultrasonographic enthesitis score in psoriatic arthritis-GRAPPA
Ultrasound Working Group. J Rheumatol. 2019;46(4):384-90.

https://doi.org/10.3899/

jrheum.171465.

32. Delle Sedie A, Riente L. Psoriatic arthritis: what ultrasound can provide us. Clin Exp Rheumatol. 2015;33(5 suppl 93):S60-5.

33. Terslev L, Naredo E, Iagnocco A, Balint PV, Wakefield RJ, Aegerter P, et al. Defining enthesitis in spondyloarthritis by ultrasound: results of a Delphi process and of a reliability reading exercise. Arthritis Care Res (Hobok). 2014;66(5):741-8. https://doi.org/10.1002/acr.22191.

34. Iagnocco A, Epis O, Delle Sedie A, Meenagh G, Filippucci E, Riente L, et al. Ultrasound imaging for the rheumatologist. XVII. Role of colour Doppler and power Doppler. Clin Exp Rheumatol. 2008;26(5):759-62.

35. Taljanovic MS, Melville DM, Gimber LH, Scalcione LR, Miller MD, Kwoh CK, et al. High-resolution US of rheumatologic diseases. Radiographics. 2015;35(7):2026-48. https://doi.org/10.1148/rg. 2015140250 .

36. Naredo E, Möller I, de Miguel E, Batlle-Gualda E, Acebes C, Brito E, et al. High prevalence of ultrasonographic synovitis and enthesopathy in patients with psoriasis without psoriatic arthritis: a prospective case-control study. Rheumatol (Oxf). 2011;50(10):1838-48. https://doi.org/10.1093/ rheumatology/ker078.

37. Zuliani F, Zabotti A, Errichetti E, Tinazzi I, Zanetti A, Carrara G, et al. Ultrasonographic detection of subclinical enthesitis and synovitis: a possible stratification of psoriatic patients without clinical musculoskeletal involvement. Clin Exp Rheumatol. 2019;37(4):593-9.

38. Faustini F, Simon D, Oliveira I, Kleyer A, Haschka J, Englbrecht M, et al. Subclinical joint inflammation in patients with psoriasis without concomitant psoriatic arthritis: a cross-sectional and longitudinal analysis. Ann Rheum Dis. 2016;75(12):2068-74. https://doi.org/10.1136/annrheumdis-2015208821.

39. Elnady B, El Shaarawy NK, Dawoud NM, Elkhouly T, Desouky DE, ElShafey EN, et al. Subclinical synovitis and enthesitis in psoriasis patients and controls by ultrasonography in Saudi Arabia; incidence of psoriatic arthritis during two years. Clin Rheumatol. 2019;38(6):1627-35. https://doi.org/ 10.1007/s10067-019-04445-0.

40. Polachek A, Li S, Chandran V, Gladman DD. Clinical enthesitis in a prospective longitudinal psoriatic arthritis cohort: incidence, prevalence, characteristics, and outcome. Arthritis Care Res 
(Hobok). 2017;69(11):1685-91. https://doi.org/10. $1002 /$ acr.23174.

41. Balint PV, Terslev L, Aegerter P, Bruyn GAW, CharyValckenaere I, Gandjbakhch F, et al. Reliability of a consensus-based ultrasound definition and scoring for enthesitis in spondyloarthritis and psoriatic arthritis: an OMERACT US initiative. Ann Rheum Dis. 2018;77(12):1730-5. https://doi.org/10.1136/ annrheumdis-2018-213609.

42. Zabotti A, McGonagle DG, Giovannini I, Errichetti E, Zuliani F, Zanetti A, et al. Transition phase towards psoriatic arthritis: clinical and ultrasonographic characterisation of psoriatic arthralgia. RMD Open. 2019;5(2):e001067. https://doi.org/10. 1136/rmdopen-2019-001067.

43. Phenix CP, Togtema M, Pichardo S, Zehbe I, Curiel L. High intensity focused ultrasound technology, its scope and applications in therapy and drug delivery. J Pharm Pharm Sci. 2014;17(1):136-53. https://doi.org/10.18433/j3zp5f.

44. Zabotti A, Idolazzi L, Batticciotto A, De Lucia O, Scire CA, Tinazzi I, et al. Enthesitis of the hands in psoriatic arthritis: an ultrasonographic perspective. Med Ultrason. 2017;19(4):438-43. https://doi.org/ 10.11152/mu-1172.

45. Funck-Brentano T, Gandjbakhch F, Etchepare F, Jousse-Joulin S, Miquel A, Cyteval C, et al. Prediction of radiographic damage in early arthritis by sonographic erosions and power Doppler signal: a longitudinal observational study. Arthritis Care Res (Hobok). 2013;65(6):896-902. https://doi.org/10. 1002/acr.21912.

46. Han J, Geng Y, Deng X, Zhang Z. Subclinical Synovitis assessed by ultrasound predicts flare and progressive bone erosion in rheumatoid arthritis patients with clinical remission: a systematic review and metaanalysis. J Rheumatol. 2016;43(11): 2010-8. https://doi.org/10.3899/jrheum.160193.

47. Hacihaliloglu I. Ultrasound imaging and segmentation of bone surfaces: a review. Technol (Singap World Sci). 2017;5(2):74-80. https://doi.org/10. 1142/S2339547817300049.

48. Gandjbakhch F, Terslev L, Joshua F, Wakefield RJ, Naredo E, D'Agostino MA, et al. Ultrasound in the evaluation of enthesitis: status and perspectives. Arthritis Res Ther. 2011;13(6):R188. https://doi.org/ 10.1186/ar3516.

49. Kamel M, Eid H, Mansour R. Ultrasound detection of heel enthesitis: a comparison with magnetic resonance imaging. J Rheumatol. 2003;30(4):774-8.

50. Taljanovic MS, Melville DM, Scalcione LR, Gimber LH, Lorenz EJ, Witte RS. Artifacts in musculoskeletal ultrasonography. Semin Musculoskelet Radiol. 2014;18(1):3-11. https://doi.org/10. 1055/s-0034-1365830.

51. Wu WT, Chang KV, Hsu YC, Hsu PC, Ricci V, Özçakar L. Artifacts in musculoskeletal ultrasonography: from physics to clinics. Diagnost (Basel). 2020;10:9. diagnostics10090645.

52. Sankowski AJ, Lebkowska UM, Cwikła J, Walecka I, Walecki J. The comparison of efficacy of different imaging techniques (conventional radiography, ultrasonography, magnetic resonance) in assessment of wrist joints and metacarpophalangeal joints in patients with psoriatic arthritis. Pol J Radiol. 2013;78(1):18-29. https://doi.org/10.12659/ PJR.883764.

53. Ran J, Morelli JN, Xie R, Zhang X, Liang X, Liu X, et al. Role for imaging in spondyloarthritis. QJ Nucl Med Mol Imaging. 2017;61(3):271-82. https://doi. org/10.23736/S1824-4785.17.02981-8.

54. Mathew AJ, Bird P, Gupta A, George R, Danda D. Magnetic resonance imaging (MRI) of feet demonstrates subclinical inflammatory joint disease in cutaneous psoriasis patients without clinical arthritis. Clin Rheumatol. 2018;37(2):383-8. https://doi.org/10.1007/s10067-017-3895-z.

55. Lambert RG, Bakker PA, van der Heijde D, Weber U, Rudwaleit M, Hermann KG, et al. Defining active sacroiliitis on MRI for classification of axial spondyloarthritis: update by the ASAS MRI working group. Ann Rheum Dis. 2016;75(11):1958-63. https://doi.org/10.1136/annrheumdis-2015208642.

56. Lukas C, Cyteval C, Dougados M, Weber U. MRI for diagnosis of axial spondyloarthritis: major advance with critical limitations "Not everything that glisters is gold (standard)." RMD Open. 2018;4(1): e000586. https://doi.org/10.1136/rmdopen-2017000586.

57. Maksymowych WP, Wichuk S, Dougados M, Jones H, Szumski A, Bukowski JF, et al. MRI evidence of structural changes in the sacroiliac joints of patients with non-radiographic axial spondyloarthritis even in the absence of MRI inflammation. Arthritis Res Ther. 2017;19(1):126. https://doi. org/10.1186/s13075-017-1342-9.

58. Rudwaleit M, Jurik AG, Hermann KG, Landewé R, van der Heijde D, Baraliakos X, et al. Defining active sacroiliitis on magnetic resonance imaging (MRI) for classification of axial spondyloarthritis: a consensual approach by the ASAS/OMERACT MRI group. Ann Rheum Dis. 2009;68(10):1520-7. https://doi.org/10.1136/ard.2009.110767. 
59. Sudoł-Szopińska I, Jurik AG, Eshed I, Lennart J, Grainger A, Østergaard M, et al. Recommendations of the ESSR Arthritis Subcommittee for the use of magnetic resonance imaging in musculoskeletal rheumatic diseases. Semin Musculoskelet Radiol. 2015;19(4):396-411. https://doi.org/10.1055/s0035-1564696.

60. Kampylafka E, Simon D, d'Oliveira I, Linz C, Lerchen V, Englbrecht M, et al. Disease interception with interleukin-17 inhibition in high-risk psoriasis patients with subclinical joint inflammation-data from the prospective IVEPSA study. Arthritis Res Ther. 2019;21(1):178. https://doi.org/10.1186/ s13075-019-1957-0.

61. Ostergaard M, McQueen F, Wiell C, Bird P, Boyesen $\mathrm{P}$, Ejbjerg B, et al. The OMERACT psoriatic arthritis magnetic resonance imaging scoring system (PsAMRIS): definitions of key pathologies, suggested MRI sequences, and preliminary scoring system for PsA hands. J Rheumatol. 2009;36(8): 1816-24. https://doi.org/10.3899/jrheum.090352.

62. Bøyesen P, McQueen FM, Gandjbakhch F, Lillegraven S, Coates L, Wiell C, et al. The OMERACT Psoriatic Arthritis Magnetic Resonance Imaging Score (PsAMRIS) is reliable and sensitive to change: results from an OMERACT workshop. J Rheumatol. 2011;38(9):2034-8. https://doi.org/10.3899/ jrheum.110420.

63. Glinatsi D, Bird P, Gandjbakhch F, Mease PJ, Boyesen P, Peterfy CG, et al. Validation of the OMERACT Psoriatic Arthritis Magnetic Resonance Imaging Score (PsAMRIS) for the hand and foot in a randomized placebo-controlled trial. J Rheumatol. 2015;42:2473-9. https://doi.org/10.3899/jrheum. 141010.

64. Mathew AJ, Krabbe S, Eshed I, Gandjbakhch F, Bird $\mathrm{P}$, Pedersen SJ, et al. The OMERACT MRI in enthesitis initiative: definitions of key pathologies, suggested MRI sequences, and a novel heel enthesitis scoring system. J Rheumatol. 2019;46(9):1232-8. https://doi.org/10.3899/jrheum.181093.

65. Poggenborg RP, Eshed I, Ostergaard M, Sorensen IJ, Moller JM, Madsen OR, et al. Enthesitis in patients with psoriatic arthritis, axial spondyloarthritis and healthy subjects assessed by "head-to-toe" wholebody MRI and clinical examination. Ann Rheum Dis. 2015;74(5):823-9. https://doi.org/10.1136/ annrheumdis-2013-204239.

66. Krabbe S, Eshed I, Gandjbakhch F, Pedersen SJ, Bird $\mathrm{P}$, Mathew AJ, et al. Development and validation of an OMERACT MRI whole-body score for inflammation in peripheral joints and entheses in inflammatory arthritis (MRI-WIPE). J Rheumatol. 2019;46(9):1215-21. https://doi.org/10.3899/ jrheum. 181084.
67. Puhakka KB, Jurik AG, Egund N, Schiottz-Christensen B, Stengaard-Pedersen K, van Overeem HG, et al. Imaging of sacroiliitis in early seronegative spondylarthropathy. Assessment of abnormalities by MR in comparison with radiography and CT. Acta Radiol. 2003;44(2):218-29. https://doi.org/10. 1034/j.1600-0455.2003.00034.x.

68. Fukuda T, Umezawa Y, Asahina A, Nakagawa $H$, Furuya K, Fukuda K. Dual energy CT iodine map for delineating inflammation of inflammatory arthritis. Eur Radiol. 2017;27(12):5034-40. https://doi. org/10.1007/s00330-017-4931-8.

69. Fukuda T, Umezawa Y, Tojo S, Yonenaga T, Asahina $A$, Nakagawa $H$, et al. Initial experience of using dual-energy CT with an iodine overlay image for hand psoriatic arthritis: comparison study with contrast-enhanced MR imaging. Radiology. 2017;284(1):134-42. https://doi.org/10.1148/ radiol.2016161671.

70. Taniguchi Y, Arii K, Kumon Y, Fukumoto M, Ohnishi T, Horino $\mathrm{T}$, et al. Positron emission tomography/computed tomography: a clinical tool for evaluation of enthesitis in patients with spondyloarthritides. Rheumatol (Oxf). 2010;49(2): 348-54. https://doi.org/10.1093/rheumatology/ kep379.

71. Van den Wyngaert T, Strobel K, Kampen WU, Kuwert T, van der Bruggen W, Mohan HK, et al. The EANM practice guidelines for bone scintigraphy. Eur J Nucl Med Mol Imaging. 2016;43(9):1723-38. https://doi.org/10.1007/s00259-016-3415-4.

72. Raza N, Hameed A, Ali MK. Detection of subclinical joint involvement in psoriasis with bone scintigraphy and its response to oral methotrexate. Clin Exp Dermatol. 2008;33(1):70-3. https://doi.org/10. 1111/j.1365-2230.2007.02581.x.

73. Scarpa R, Cuocolo A, Peluso R, Atteno M, Gisonni P, Iervolino S, et al. Early psoriatic arthritis: the clinical spectrum. J Rheumatol. 2008;35(1):137-41.

74. Gheita TA, Azkalany GS, Kenawy SA, Kandeel AA. Bone scintigraphy in axial seronegative spondyloarthritis patients: role in detection of subclinical peripheral arthritis and disease activity. Int J Rheum Dis. 2015;18(5):553-9. https://doi.org/10.1111/ 1756-185X.12527.

75. Ezziddin S, Khalaf F, Seidel M, Al-Zreiqat A, Wilsmann-Theis D, Simon B, et al. Introduction of a metabolic joint asymmetry score derived from conventional bone scintigraphy. A new tool to differentiate psoriatic from rheumatoid arthritis. Nuklearmedizin. 2015;54:183-9. https://doi.org/10. 3413/Nukmed-0698-14-09. 
76. van der Heijde D, Mease PJ, Landewé RBM, Rahman P, Tahir H, Singhal A, et al. Secukinumab provides sustained low rates of radiographic progression in psoriatic arthritis: 52-week results from a phase 3 study, FUTURE 5. Rheumatol (Oxf). 2020;59(6): 1325-34. https://doi.org/10.1093/rheumatology/ kez420.

77. Acquacalda E, Albert C, Montaudie H, Fontas E, Danre A, Roux $\mathrm{CH}$, et al. Ultrasound study of entheses in psoriasis patients with or without musculoskeletal symptoms: a prospective study. Joint Bone Spine. 2015;82(4):267-71. https://doi. org/10.1016/j.jbspin.2015.01.016.

78. Smolen JS, Schols M, Braun J, Dougados M, FitzGerald O, Gladman DD, et al. Treating axial spondyloarthritis and peripheral spondyloarthritis, especially psoriatic arthritis, to target: 2017 update of recommendations by an international task force.
Ann Rheum Dis. 2018;77(1):3-17. https://doi.org/ 10.1136/annrheumdis-2017-211734.

79. Eshed I, Bollow M, McGonagle DG, Tan AL, Althoff $\mathrm{CE}$, Asbach P, et al. MRI of enthesitis of the appendicular skeleton in spondyloarthritis. Ann Rheum Dis. 2007;66(12):1553-9. https://doi.org/ 10.1136/ard.2007.070243.

80. Micu MC, Fodor D. Concepts in monitoring enthesitis in patients with spondylarthritis-the role of musculoskeletal ultrasound. Med Ultrason. 2016;18(1):82-9. https://doi.org/10.11152/mu. 2013.2066.181. $\mathrm{mcm}$.

81. Perazella MA. Gadolinium-contrast toxicity in patients with kidney disease: nephrotoxicity and nephrogenic systemic fibrosis. Curr Drug Saf. 2008;3(1):67-75. https://doi.org/10.2174/ 157488608783333989. 